\title{
Molecular dependence of hippocampal bidirectional plasticity
}

\author{
Joanna Jędrzejewska-Szmek*, Andrew Chay, Kim T Blackwell \\ From The Twenty Third Annual Computational Neuroscience Meeting: CNS*2014 \\ Québec City, Canada. 26-31 July 2014
}

Hippocampal plasticity inducing protocols vary in their activation of signal transduction pathways and resulting dependence on signaling molecules. Many long-term potentiation (LTP) inducing paradigms require both memory kinases: calcium-calmodulin dependent protein kinase II (CaMKII) and protein kinase A (PKA) signaling pathways.

Both CaMKII and PKA are activated by calcium bound calmodulin, CaMKII directly, and PKA indirectly via adenylyl cyclase production of cAMP. The adenylyl cyclase is also activated by stimulation of beta-adrenergic receptor ( $\beta A R)$. Curiously, not all forms of cAMP dependent LTP require PKA. Specifically, LTP induced with isoproterenol (ISO) bath application followed by $100 \mathrm{~Hz}$ stimulation is PKA independent [1,2], whereas both ISO followed by $3 \mathrm{~min}$ of $5 \mathrm{~Hz}$ [2] and four trains of $100 \mathrm{~Hz}$ stimulation do require PKA [3]. Furthermore, recent experiments suggest a novel $\beta A R$ signaling pathway, in which PKA phosphorylation prevents activation of $G$ protein subtype $\mathrm{s}(\mathrm{Gs})$, and switches the $\beta A R$ to the $\mathrm{Gi}$ subtype of G [4], leading to recruitment of another memory kinase: extracellular signal-regulated kinase (ERK).

To investigate how temporal pattern of synaptic activation determines which signaling pathways are activated, we employed a multi-compartmental stochastic reactiondiffusion model of calcium and cAMP activated signaling pathways. We investigated two model variants, one which took into account only $\beta$ ARcoupling to Gs, and the other which included the novel switching pathway. We performed simulations of four trains of $100 \mathrm{~Hz}$, and isoproterenol application followed by either 1 train of $100 \mathrm{~Hz}$ or $3 \mathrm{~min}$ of $5 \mathrm{~Hz}$, all of which produce long lasting LTP. We also simulated 3 stimulation paradigms

\footnotetext{
* Correspondence: jjedrzej@gmu.edu

The Krasnow Institute for Advanced Study, George Mason University, Fairfax,
} VA 22030, USA

which do not produce LTP, including $1 \mathrm{~Hz}$ stimulation which produces LTD.

Our results using the first model could not explain and predict the direction of synaptic plasticity based only on CaMKII, PKAc and phosphatases activity, especially for paradigms that do not induce plasticity, such as bath application of isoproteronol.

Experimentally, isoproteronol does not cause LTP despite $\beta A R$ activation resulting in cAMP synthesis [2], suggesting that $\beta A R$ undergo PKA dependent desensitization, that changes their coupling from Gs (stimulating adenylyl cyclases and cAMP synthesis) to Gi. Gi coupling both inhibits adenylyl cyclase, limiting the elevation in cAMP in response to bath application, and provides free Gi $\beta \gamma$, which recruits molecules leading to ERK [5]. Including PKA dependent switching from Gs to Gi resulted in a model which could explain which molecules are activated in 5 LTP induction paradigms, 1 LTD induction paradigms, and 2 induction paradigms that do not produce plasticity. The model also allowed for proposing a measure of plasticity direction. The measure took into account activation of CaMKII, PKA, Gi $\beta \gamma$ (representing ERK), Epac and influence of phosphatase activity.

\section{Acknowledgements}

We kindly acknowledge support from ONR grant MURI N00014-10-1-0198 and CRCNS program NIH R01 AA018060

Published: 21 July 2014

\section{References}

Gelinas JN, Banko JL, Peters MM, Klann E, Weeber EJ, Nguyen PV: Activation of exchange protein activated by cyclic-AMP enhances long-lasting synaptic potentiation in the hippocampus. Learn Mem 2008, 15(6):403-11.

2. Gelinas JN, Tenorio G, Lemon N, Abel T, Nguyen PV: Beta-adrenergic receptor activation during distinct patterns of stimulation critically modulates the PKA-dependence of LTP in the mouse hippocampus. Learn Mem 2008, 15(5):281-9. 
3. Woo NH, Duffy SN, Abel T, Nquyen PV: Temporal spacing of synaptic stimualtion critically modulates the dependence of LTP on cyclic AMPdependent protein kinase. Hippocampus 2003, 13(2):293-300

4. Daaka Y, Luttrell LM, Lefkowitz RJ: Switching of the coupling of the beta2adrenergic receptor to different $\mathrm{G}$ proteins by protein kinase A. Nature 1997, 390(6655):88-91.

5. Enserink JM, Christensen AE, de Rooij J, van Triest M, Schwede F, Genieser HG, Døskeland SO, Blank JL, Bos JL: A novel Epac-specific cAMP analogue demonstrates independent regulation of Rap1 and ERK. Nat Cell Biol 2002, 4(11):901-6.

doi:10.1186/1471-2202-15-S1-P204

Cite this article as: Jędrzejewska-Szmek et al:: Molecular dependence of hippocampal bidirectional plasticity. BMC Neuroscience 2014 15(Suppl 1): P204.

Submit your next manuscript to BioMed Central and take full advantage of:

- Convenient online submission

- Thorough peer review

- No space constraints or color figure charges

- Immediate publication on acceptance

- Inclusion in PubMed, CAS, Scopus and Google Scholar

- Research which is freely available for redistribution

Submit your manuscript at www.biomedcentral.com/submit 